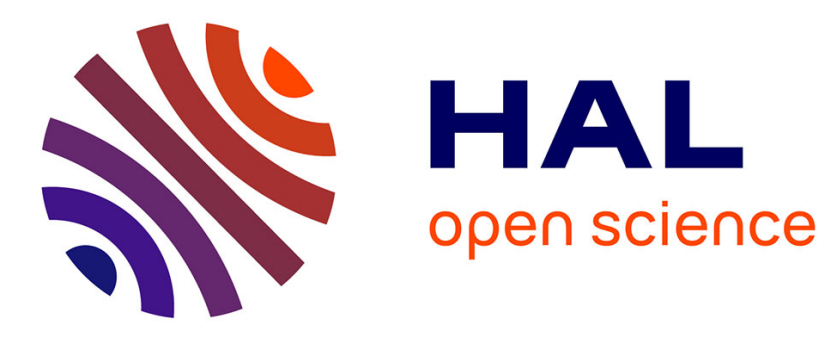

\title{
Ordinary elections and constitutional arrangements
}

Pierre Salmon

\section{To cite this version:}

Pierre Salmon. Ordinary elections and constitutional arrangements . [Research Report] Laboratoire d'analyse et de techniques économiques(LATEC). 1999, 22 p., ref. bib. : dissem. hal-01526528

\section{HAL Id: hal-01526528 \\ https://hal.science/hal-01526528}

Submitted on 23 May 2017

HAL is a multi-disciplinary open access archive for the deposit and dissemination of scientific research documents, whether they are published or not. The documents may come from teaching and research institutions in France or abroad, or from public or private research centers.
L'archive ouverte pluridisciplinaire HAL, est destinée au dépôt et à la diffusion de documents scientifiques de niveau recherche, publiés ou non, émanant des établissements d'enseignement et de recherche français ou étrangers, des laboratoires publics ou privés. 


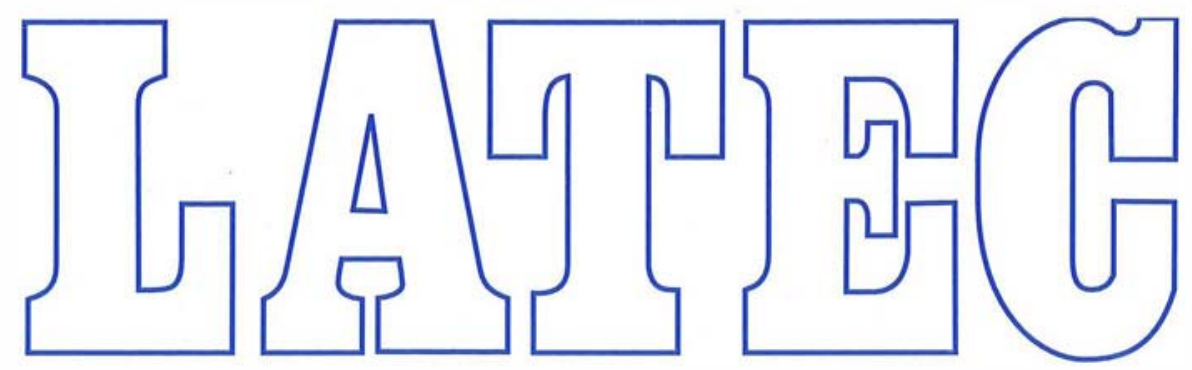

\section{LABORATOIRE D'ANALYSE ET DE TECHNIQUES ÉCONOMIQUES}

UMR 5118 CNRS

DOCUMENT DE TRAVAIL

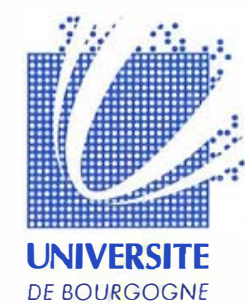

Pôle d'Économie et de Gestion

2, bd Gabriel - BP 26611 - F-21066 Dijon cedex - Tél. 0380395430 - Fax 0380395443

Courrier électronique : secretariat.latec@u-bourgogne.fr 
$n^{\circ} 9910$

Ordinary elections and

constitutional arrangements

\author{
Pierre SALMON
}

July 1999 



\title{
Ordinary Elections and Constitutional Arrangements
}

by

\author{
Pierre Salmon
}

Université de Bourgogne

LATEC

\begin{abstract}
It is widely held that voting in the course of ordinary elections has no significant influence on the constitutional regime or order of a country. At least three powerful arguments are provided in support of that view. First, to claim that, at the same time as they play, players can change the rules is, to say the least, logically puzzling. A second argument refers to the motivations and possibilities of voters: voters, this argument says, are not really interested in constitutional issues and, even if they were, are particularly ill-equiped to understand their implications. The third argument rests on the observation of what obtains in practice: as a matter of fact, constitutional issues are generally absent from electoral campaigns. After a discussion of what should be included in the constitutional "order, "regime" or "arrangements" of a country, the paper endeavours to neutralize each of the three arguments and show that voters do exercise a very susbstantial influence on constitutional matters simply by the way of their vote in ordinary elections.
\end{abstract}

Keywords: constitutional economics, elections, constitutional change

Mots-clefs: économie constitutionnelle, élections, changements constitutionnels 


\section{Introduction}

It is widely held that voting in the course of ordinary elections has no significant influence on the constitutional regime or order of a country. If voters have at all any influence on the constitutional set-up, which not everybody sees as evident, ${ }^{1}$ this is generally considered to occur only on the relatively rare occasions when constitutional questions are submitted to a referendum or to a specially elected convention or constitutional assembly. At least three arguments are provided to support that opinion. A logical consideration comes first. Ordinary elections are parts of the political game and thus logically take place within the rules of that game - that is, within the constitutional order or regime of the country. To assume that, at the same time as they play, players can change the rules is, to say the least, logically puzzling. The second argument refers to the motivations and possibilities of voters. Voters, this argument says, are not really interested in constitutional issues and, even if they were, are particularly ill equipped to understand their implications. The third argument rests on the observation of what obtains in practice. As a matter of fact, constitutional issues are generally absent from electoral platforms and campaigns.

In spite of its apparent strength, this three-pronged denial is not compelling, I will try to show. To defend the opposite view - that voters do exercise a substantial influence on constitutional matters simply by the way of their vote in ordinary elections - I will endeavour to neutralise each of the three arguments mentioned above. The organisation of the paper reflects this objective. Thus I will explain in Section 3 why I think that ordinary elections having constitutional effects implies no logical contradiction; discuss in Section 4 voters' capacities and motivations, and argue in Section 5 that voters' influence on constitutional or institutional matters is compatible with the observation that these matters seldom come to the fore in electoral debates. But before proceeding to the main discussion, I must address in

\footnotetext{
1 Although the assumption that they have is implicit in the way the constitutional economics school sees its prescriptive or normative role (see, e.g., Vanberg, 1994).
} 
Section 2 the question of what one may want to include in the "constitutional regime" or "order". 2

\section{What is constitutional?}

By definition, the question is largely semantic but (pace Karl Popper and Milton Friedman) this does not mean that it is meaningless. In some cases, notably that of the United States, it is at least feasible or conceivable to equate the constitutional regime or order and the formal (paper) constitution itself. If this is done, then, because formal constitutions cannot be changed by simple majorities of voters, ${ }^{3}$ it is trivially true that the constitutional order cannot be changed in this way either. However, in many cases, it is not feasible or conceivable to equate the constitutional regime with a constitution either because there is no such thing or because the one that exists is largely irrelevant. Furthermore, even when it is conceivable, the assimilation is, I would say, generally inadvisable. It implies for example that countries that have the same constitution have the same constitutional regime, which is not exactly what one would want to say of all the countries whose constitution was modelled on that of the United States. It also leads to the neglect of rules of the game which, albeit absent from the formal constitution, constitute major constraints on the way the game can be played and thus deserve to be considered, in some sense, "constitutional". ${ }^{4}$

In a country such as France, there are at least four sets of rules or arrangements that we might want to include in the constitutional regime although they are either not addressed at all or only alluded to in the formal constitution. One is the electoral system. The other three

\footnotetext{
2 "Constitutional order" is a bit pompous; it should be understood as more or less synonymous with "constitutional set-up", "regime", "system", "set of rules", "arrangements", etc.

3 Disregarding the case of countries, such as Britain, which have no formal constitution, only in Iceland is a 51 per cent majority sufficient to change the constitution.

4 James Buchanan (1987) refers to the "set of legal-institutional-constitutional rules that constrain the choices and activities of economic and political agents" or, somewhat more economically, to the "legal-institutionalconstitutional structure of the polity."
} 
concern the rules which govern the relations between the politicians in power in the central government in Paris, on the one side, and, on the other side, first the bureaucracy, second the subnational elected governments (i.e., municipal, departmental and regional governments), third, the European institutions in Brussels. Whatever their origin or status, the rules or arrangements currently in force in these four areas have a considerable incidence not only on political life in general but also on matters that are addressed at length by the formal constitution.

I will refer to decentralisation and to the relationship between politicians and bureaucrats in subsequent sections. At this stage let me give some illustrations of the constitutional relevance of Europe and of the electoral system. With regard to Europe, the European Court of Justice itself has repeatedly referred to the EEC Treaty as, "albeit concluded in the form of an international agreement", being "the basic constitutional charter" (see Weatherill 1995, p. 184). This is not a purely rhetorical claim on the part of an institution whose objectivity on this point could be suspected. The constitutional relevance of the European treaties can be illustrated in many ways. For instance, many scholars, especially among economists, consider the protection of individual rights of a more economic kind (property, income from capital, etc.) to be an essential task of constitutions. The French constitution does fulfil in part this function, as the Socialist government discovered in 1981 when it was compelled by the Conseil Constitutionnel to raise the compensation paid to the owners of the firms transferred to the public sector. But this constitution is not in France the only protector of property rights. It is more than supplemented in this task by the rules adopted in the context of European integration for promoting the free movement of goods, factors and persons. One might even argue that, at the present stage of European integration (this could change at a later stage), the main protection of economic rights lies in the existence of these rules rather than in the constitutions of the member states. For instance, the former, not the latter, prevent in fact recourse to a confiscatorily high level of taxation of 
income or capital. The European rules concerned here legally constrain governments and thus should not be confused with the market forces referred to under the name of globalisation. Because of this legally compelling character some at least of these European rules should be considered as essential components of the constitutional order currently prevailing in France, or for that matter in other member countries. ${ }^{5}$

Another example concerning Europe is budgetary discipline. There is a provision in the French constitution (Article 40) that says: "The proposals and amendments initiated by members of parliament cannot be taken into consideration when their adoption would either reduce the fiscal revenue or impose a financial burden on the budget". ${ }^{6}$ In the past, this may have contributed to budgetary discipline by making more transparently the executive branch of government responsible for any lack of it. But today the disposition has lost much of its relevance. It is overshadowed by the budgetary requirements imposed at the European level in the context of monetary unification. ${ }^{7}$

Let us turn to the electoral sytem. Its importance in the characterisation of the political system of a country needs not be stressed. Among many possible sources, a particularly illuminating one is Giovanni Sartori's excellent little book (1994) on "constitutional engineering". This term, Sartori indicates (p. 140), should be understood as "a shorthand that includes the electoral system, even though electoral systems are generally determined by ordinary legislation". Many examples of the close relationship between various aspects of the formal constitution and the electoral system can be found in Sartori's book: for instance, in the

\footnotetext{
5 This point is particularly important in the case of a country such as Britain, where, according to Walter Murphy (1993), "Parliament is supposedly the authoritative creator, emendator, and interpreter of the constitution, restrained only by the ballot box and its collective conscience", but only inasmuch as the European Economic Community or the European Convention on Human Rights are not involved (p. 15). In other words, in Britain the only formal constitutional constraints on parliamentary sovereignty are the European institutions.

6 See Sartori, 1994, p. 201.

${ }^{7}$ For an interesting analysis of the close relationship that may exist between constitutions and treaties, see Ackerman (1997). For Bruce Ackerman (p. 9), "the (uncertain) transformation of a treaty into a constitution is at the center of the European Union today; it was also at the center of the American experience between the Revolution and the Civil War". See also Weatherill (1995, chapter 6).
} 
"English system of government", the crucial importance of plurality voting (p. 104); or, in the "Washington model", of the way representatives are induced by the electoral system to concentrate on local interests, a characteristic that contributes to avoid deadlocks when the two branches of government are held by different parties (pp. 86-91).

A question that Sartori does not raise, at least in this book, is why electoral systems, despite their importance in constitutional matters, are seldom included in formal constitutions. One reason might be that if they were, they could well turn out to be unfortunate given other features or circumstances of the countries concerned. The Weimar constitution and the constitution adopted in France under the Fifth Republic are similar in many respects. However, the former (in its Article 22) imposed proportional representation whereas the latter imposed nothing. It seems agreed among specialists of Weimar that the pure system of proportional representation (applied to a single national constituency) that it used at least "exaggerated the multiplicity and divisiveness of German politics in the Reichstag" (Finn, 1991, p. 145). ${ }^{8}$ By contrast, a major effect of an electoral system like the double ballot majority system used in France is to reduce the representation in parliament of "anti-system" parties (Sartori, 1994, pp. 67-69). ${ }^{9}$ There are other means available for that purpose. ${ }^{10}$ Among these, a particularly illustrative one was the apparentement system contrived in France in 1951 by the parties of the centre-left and centre-right to safeguard a majority of seats endangered by the converging electoral forces of the Gaullists and the Communists. ${ }^{11}$ Without this device, allowed by the fact that electoral rules were not too difficult to change, it

\footnotetext{
8 Sartori (1994, p. 129) writes: "Pace Lijphart, more than by any other factor Weimar was undermined by PR [proportional representation] (a defect remedied by the French with the double ballot majority system)."

${ }^{9}$ Possibly even (when access to the second round is limited to the first two runners) when one such anti-system party is the relative winner in the first round (Sartori, 1994, note 17, p. 78).

10 Including making anti-system parties anti-constitutional and dissolving them, as was done in West Germany.

11 The scheme gave the electoral alliance which obtained a relative majority a premium sufficient for it to have the majority in parliament although it (the scheme) maintained proportional representation within the alliance (see Sartori, 1994, pp. 6-7). A combination of proportional representation with a majoritarian premium is currently the rule in France for municipal elections. It works very well.
} 
is quite possible that the Fourth Republic would have come to an end earlier than it did. Among others, the opposite cases of Weimar and of the apparentements show that the fact that an electoral system is not part of the formal constitution, and thus can be changed more easily, may actually contribute to the survival of the constitutional regime - a consideration that constitutional framers may well have had in mind in the first place.

Electoral systems can thus be seen to be a priori less permanent or structural than the dispositions included in the formal constitutions. In practice, however, it is often the case that electoral systems prove to be more stable or enduring than many of these dispositions. In any case, I think, together with many authors, that electoral systems are an essential characteristic of political systems at the constitutional level. From the perspective of this paper, the most important feature of an electoral system is whether it allows a swift replacement of officeholders or of policies considered as unsatisfactory by a majority of voters. Indeed, as will become clear, if an electoral system has this property, it may well turn out to be a more essential component of the constitutional order than most other components.

\section{Elections and the constitutional logic}

A large part of the literature on constitutions and almost all of that small part of it which is produced by economists reflects what has been called "constitutionalism", that is, an exclusive concern with constraining, circumscribing, or binding majorities of voters.

A degree of mistrust of the majority of voters was expressed by James Madison among others (e.g., Benjamin Constant in France). For instance, Madison wrote:

In our Governments the real power lies in the majority of the Community, and the invasion of private rights is chiefly to be apprehended, not from acts of Government contrary to the sense of its constituents, but from acts in which Government is the mere instrument of the major number of constituents. ${ }^{12}$

\footnotetext{
12 Letter of October 17, 1988 to Thomas Jefferson (quoted by Murphy, 1993, p. 6).
} 
The reasons for constraining the freedom of decision of majorities of voters are well known. First, there is the protection of individual rights. In the long run and under a "veil of ignorance" all citizens may favour such protection, but in the short run there may be powerful incentives for a majority to transgress them. Hence the usefulness of binding (see, e.g., Buchanan, 1990). Second, in some cases, there may be the protection of perfectly identified and permanent minorities - ethnic, religious or linguistic minorities in particular. This protection may be accepted by a majority at 'a constitutional stage' because of ethical principles, or as a consequence of some constitutional logrolling, or just for the purpose of safeguarding internal peace. Third, the protection of property rights of an economic kind can be understood as an aspect of the protection of rights in general or as a means to foster investment and growth (which in turn may be deemed necessary for democratic stability, as argued among others by Peter Bernholz, 1997). Fourth, independently of the other reasons, constraining the majority of voters may be necessary to render more credible some commitments, either promises or threats. For instance, making central banks independent may be away to solve the time-inconsistency problem that plagues government policy-making in matters of money and inflation; or the constitutionally protected independence of judges and non-retroactivity of the law may be, as a side-effect, a means for a country to avoid being blackmailed by terrorists.

Inasmuch as constitutional rules and arrangements are seen as exclusively concerned with the task of binding majorities of voters, there is something akin to a logical contradiction in the possibility that these majorities could change the constitutional rules and arrangements. Leaving them this freedom would be akin to leaving Ulysses the freedom to unbind himself. I wonder whether, even more than a normative concern, it is not this logical issue which underlies Dennis Mueller's reaction to the view, defended in particular by Bruce Ackerman 
(1991), that simple electoral majorities do in fact change the constitutional order. ${ }^{13}$ That in the United States the constitutional order has changed a lot without formal constitutional amendments has been a major theme in the public choice and constitutional economics literature for some time (see, e.g., Buchanan, 1975; McKenzie, 1984; Wagner, 1987; Gwartney and Wagner, 1988; Niskanen, 1990). But inasmuch as the responsibility for this phenomenon is ascribed to the Supreme Court or to politicians, it raises a possibly difficult question about constitutional enforcement but no logical problem. The specificity of Ackerman's book is the claim that the ultimate legitimate source of the change in the constitutional order is to be found in the opinion or will of a majority of voters. Pushed too far this kind of argument is destructive of the notion of constitutional binding in general. It is clear that Ackerman himself is conscious of this danger. He insists on a number of requirements to be satisfied before it becomes possible for a majority to change the constitutional rules and on the paucity of situations in which these requirements have been met. The logical problem raised by 'self-unbinding' (if I may use that term) is mitigated or solved when there are obstacles and costs to unbinding. Thus it is natural to impose conditions for constitutional change brought about by elections as demanding as those included in formal amendment procedures.

Constitutions, however, have a second function that does not raise this kind of problem when considered in isolation. This second function consists in organising the principal-agent relation between voters (the principals) and their representatives (agents). The problem then is to design institutions and rules in such a way that the preferences or interests of a majority of voters get satisfied. Under that second perspective, there is nothing strange or self-destructing

\footnotetext{
13 Mueller (1996, p. 337, note 20) raises the question "To what extent does a minority remain party to the constitutional contract, if the contract can be amended whenever a substantial majority so chooses?" In reality this question is far-reaching. It points to a puzzle that affects the whole construction of constitution-as-contract (see Hardin, 1990, and Ordeshook, 1992).
} 
in simple majorities of voters changing some rules or institutions in view of getting a better alignment between government decision-making and their preferences or interests.

It is understandable that, for the majority of authors concerned with constitutional economics - that is, with individual rights - this second perspective is of little importance. Whether the government or the legislature violates the constitutional rules protecting minorities and rights because, as an agent, it does not itself respect the mandate or trust received from a majority of voters or because the majority of voters itself has an interest in these rules being violated is relatively secondary. In the vocabulary employed in some of this literature, the important issue is whether what gets favoured is "predation" or "exchange" (Wagner, 1987). If, with the complicity of the courts, what gets favoured is predation, it does not really matter whether the predator is a majority of voters, a set of office-holders, or, more likely, a combination of the two.

Without adopting this position, one must admit that disentangling the two functions of constitutional or quasi-constitutional rules or arrangements is not an easy task. What constitutions do, materially, is to restrict politicians, not directly voters. In so doing they at the same time, in generally unknown or undecidable proportions, fulfil the two tasks of fostering the interests of a majority of voters (the principal-agent perspective) and of restraining the same voters (the constitutionalist perspective). For instance, constitutional provisions concerned with budgetary discipline, such as the already mentioned Article 40 of the French constitution, or like the much more ambitious constitutional constraints defended for the United States by Buchanan and others, reflect a distrust indistinctly of legislators and of majorities of voters.

For the purpose of justifying my proposition, what creates a problem is when the representatives of a majority of voters change components of the constitutional order in the direction of increased power or freedom for themselves. Let me assume that this is done with the acquiescence of voters. If one could be sure that the change has no bearing on the first 
function of the constitution (concerning the relations between voters), but only on the second function (concerning the agency relationship between voters and their representatives), it could be considered as non-destructive of constitutional principles. But I am not sure that ascertaining independent effects in such a way is even only sometimes possible. Thus, as already noted, taking into account principal-agent considerations changes nothing in practice to our logical problem. Since this is the situation which Buchanan and his followers focus on, they are not inconsistent. ${ }^{14}$ When, on the contrary, with the approval of voters as expressed in ordinary elections, representatives change components of the constitutional order in the direction of decreased power or freedom for themselves, the logical problem is more or less absent. Extra self-binding is much les puzzling than self-unbinding, so to say. Of course, such behaviour may be puzzling for other reasons. One problem may be solved but others arise. I turn to some of the other problems now.

\section{Voters' concerns and capabilities}

Consumers are not generally concerned with how production is organised. Similarly, it is often claimed that voters are and/or should be concerned only with the outputs of governmental activity and the cost or tax prices associated with these outputs and not with the internal organisation of the state. One possible reason for their unconcern could be that they can trust their representatives, the elected politicians, to organise the state in their (the voters') interests. Another possibility is that voters can rely on their assessment of policy outputs and tax prices, combined with voting, as sufficient to ensure that they are provided with the policies they want. The reason which is probably the one most people think of in priority is that voters are completely ignorant of constitutional matters and know that they are.

\footnotetext{
14 Whether their factual beliefs or interpretations are true is another matter, discussed for instance by Wittman, 1995, pp. 137-48, with regard to "takings" clauses.
} 
Although apparently convincing this last argument is possibly the weakest. It is probably true that most voters are rather ignorant of the way government is organised. However, the main features of this organisation or the main problems that it raises are not more difficult for them to understand than many other issues, economic and social issues in particular, which they are not supposed to be completely unable to understand in most accounts of electoral behaviour. Compare for instance the informational problems involved in deciding whether the president should be elected for five years with a possibility of being reelected once, for seven years with also this possibility, or for seven years without it, and the information required to answer the question of whether a lot of influence on employment is lost when monetary policy becomes unavailable as a consequence of fixed exchange rates or monetary unification. Both questions are or have been recently part of the political debate in France. The first is typically constitutional but it calls for considerations that many citizens are perfectly able to grasp, it seems to me. The second calls for an understanding and comparative assessment of full-blown models (involving expectation-augmented Philips curves, time inconsistency, sunspot equilibria and what have you) that should tax the analytical capacity of the most competent economists. I do not say that voters are deprived of any means of making their mind on these matters as on others (see Wittman, 1995, chapter 1), but I refuse to adopt the widely-shared presumption that issues similar to the second question, typical of the most relevant questions in the economic domain, are more easily decidable by voters than questions alike the first, typical of the constitutional agenda.

Let me turn now to the question of whether, assuming that they are sufficiently competent, voters should be concerned with constitutional or quasi-constitutional issues, pertaining for instance to the organisation of the relationship between politicians and bureaucrats. ${ }^{15}$

\footnotetext{
15 In Section 2, I mentioned three relationships whose organization should be considered, in the case of France at least, to be part of constitutional arrangements. In work published previously (Salmon, 1987, 1991, 1995), I
} 
When economists discuss the relations between politicians and voters, they tend since the mid-1980s to adopt the principal-agent framework. They model bureaucrats as the agents of elected politicians. At the same time, they assume elected politicians to be the agents of voters and they treat these two agency relationships as if they were independent. This implicit assumption has unfortunate consequences. It implies that the stronger the agency relationship between politicians and bureaucrats, the better from the standpoint of voters, whatever the state of their relationship with politicians. But, when the relationship between voters and politicians is defective (as is necessarily the case in our actual, generally imperfect, world), it is far from clear that voters should wish the relation between politicians and bureaucrats to be as good or tight as possible (supposing that they should is a mistake akin to the mistake whose elimination motivated the theory of the second best). For instance, if we do not trust our president or Prime Minister, do we wish him to enjoy a perfectly symbiotic relationship with the head of the police? If the assumptions that could justify a positive answer to that question were stated explicitly, it would be clear that they are unacceptable, but they are usually made implicitly in the context of the study of one of the two relationships at the time. This allows many authors to suppose, as if it were obvious, that a perfect control of politicians over the bureaucracy would be a good thing for democracy, that a major problem of our democratic societies is that this control is highly imperfect.

For our purpose, what the foregoing discussion suggests is that voters could remain completely unconcerned with the organisation of relations between politicians and bureaucrats only if they could fully trust their representatives, the politicians, to shape these relations in their (the voters') best interests. I have some sympathy for the minority view, defended notably by Albert Breton (1996, e.g.) and Donald Wittman (1995, e.g.), that in Salmon (1997). 
powerful mechanisms are at work which make politicians exert themselves and respond fairly well to the preferences of voters (not worse than business firms with regard to the preferences of consumers, to use a comparison both authors make). However, even if we accept this general perspective, I think that at least two sets of considerations prevent us from considering the relationship between voters and politicians as unproblematic. One set is related to what is known as the "fear of the state": voters may be afraid or distrustful of the power of the rulers or they may be afraid or distrustful of their fellow voters or of themselves. Even accepting Breton's view that the government or the state is not a monolith, that "governemental systems" are very competitive, the question remains of whether voters can rely in all circumstances on this competition. It is not inconceivable, for instance, that a single disciplined party could conquer many centres of power, at all levels of jurisdiction, and then that its leaders could misuse the considerable power that such concentration or monopolisation would provide them with. Since the damage caused by a chain of events of that kind could be serious, a small probability of its occurrence would be sufficient to justify the fear of the state on the part of risk-averse citizens. The existence of relatively independent or protected non-elected decision-makers, such as civil servants and judges, might be valuable to voters under that perspective. Even closer to counterfactual reasoning, another question arises: is the fragmentation of the state into smaller mutually competitive units independent of the fear of the state? The checks and balances and other institutional arrangements which allow competition to develop may themselves have something to do with that fear.

A second set of qualifications is related to the fact that, while retrospective assessments necessarily play a major role in the vote, they cannot bear with the same reliability or strength on all policies or aspects of policies. To refer to my own work (1987, e.g.), I have called performance competition a mechanism based on the assumption that office-holders in one jurisdiction know, albeit with some degree of uncertainty, that many voters in their electorate compare policy outcomes in the jurisdiction to policy outcomes elsewhere. This gives office- 
holders an incentive to exert themselves, that is, in some sense, to move the policy-mix toward the production frontier. If this mechanism worked perfectly well, voters could concern themselves exclusively with policy outputs and disregard completely the way governments are organised (provided of course that their power to dismiss is safeguarded by the electoral rules). However, a major problem that this mechanism encounters, or more generally that any mechanism based on retrospective voting encounters, stems from the fact that policy outputs are not equally measurable by voters. As a consequence, politicians may be induced to concentrate their efforts on policies whose outcomes are more easily measurable and sacrifice other policies which would also be useful to voters (see Salmon, 1991; Tirole, 1994; and, in a more general context, Holmström and Milgrom, 1991).

Policies yielding benefits only in the long run may be particularly vulnerable to distortions of that kind. Admittedly, some aspects of these policies may well be relatively easily assessable by voters before they bear fruit: voters may understand that investment in tangible or human capital may be favourable to future growth, they may welcome land reclamation or reforestation programmes, they may perceive or accept the claimed causality between new laws or new agencies and some relatively distant objectives. There are however many aspects of long-term oriented policies which they will find more difficult to observe or assess. The literature on the interaction between the polity and the bureaucracy focuses on making and implementing rules, changing policies, creating agencies. But the major part of what the state or the government does, and should be doing, is more basic and less related to change. As a matter of course, the state (including subcentral governments) provides citizens with a regular and continuous flow of . Maintaining the future capacity to deliver these services, at a constant and sufficient level of quality, is typically a long-term policy which cannot easily be assessed by voters. If political competition is very severe, which may be a good thing in itself, this might well have the unfortunate side-effect of literally compelling incumbents to sacrifice all policies which do not 'pay' in terms of probability of re-election, 
this kind of policy in particular. The organisation of the state, including for instance an institution such as the civil service, may mitigate that problem. But it is unlikely to follow such an objective if voters leave politicians free to shape it according to their (the politicians') preferences.

The foregoing discussion shows, I hope, that voters should not trust completely the politicians, or the perfection of the agency or delegation relationship which they have with politicians, and should not be unconcerned by the organisation of government. The question now is whether they can and do have an influence on this organisation. This needs dealing with the observation that this type of issues seems to be more or less absent from electoral campaigns.

\section{Institutional or constitutional issues in elections}

Many of these issues are dealt with on the occasion of formal constitution making or amending. Others, such as the ones we focus on in this paper cannot. For instance, the relationship between the polity and the bureaucracy is not addressed in formal constitutions. The relations between the central government and subcentral governments is not based on a distribution of constitutional rights in unitary states - or even, for that matter, in all federal states (see Ordeshook, 1992, p. 167). This means that the form of institutional design which is of interest to us is not of a constitutional kind in the formal sense of that term. Received wisdom is that institutional design or change which is not of a constitutional kind in the formal sense is the business of politicians, or perhaps the result of spontaneous evolution, but cannot be in any case influenced by voters in the course of ordinary elections. In addition to the idea, discussed in the preceding section, that voters have neither the motivations nor the capacities to be concerned with these issues, what could make the influence of voters on institutions (by the means of ordinary elections) somewhat doubtful is that institutional issues seldom become salient issues in electoral contests. 
Seldom is not "never" and in a sense it might not be abnormal that constitutional issues come to the fore only intermittently or discontinuously. On some occasions, it is the case that voters clearly want institutional change. Then, we can often count on political entrepreneurship to bring that change about. In the United States as in France, presidents or candidates in presidential elections are the most likely constitutional entrepreneurs. But this may be relatively recent phenomenon (see Ackerman, 1991). An American illustration of a process starting from below is the way the Progressive movement imposed reforms at the turn of the century, in particular at the level of municipal government (see, e.g., Maser 1985, Knott and Miller 1987). Municipal governments were typically dominated by party machines under a generalised system of patronage. Although this often worked well or speedily in terms of policy outputs, many voters, especially in the middle classes, were revolted by at least some aspects of the system. The National Municipal League pushed for a reform including the introduction of a relatively neutral or independent civil service for government employees. The issue became a salient one in elections at the local and state levels. As a result, many municipal charters were changed. Although the story is complicated, with some moot points (see the discussion following Maser's paper and the references in Knott and Miller), it seems generally agreed that the discontent of a large part of the electorate with the existing institutions was a major cause of their reform. Other examples that come to mind are in the United States the anti-slavery movements before the Civil War and the civil rights movement in the $1960 \mathrm{~s}$, in various countries the women's suffrage movement.

Even if we accept that open "constitutional politics" at the electoral level is infrequent, this fact may not reflect a disinterest of voters for institutional issues but the existence of an attachment of voters to the institutional status quo and the knowledge of this preference by politicians (it is natural enough that attachment to the status quo plays an important role in constitutional and institutional matters). 
In the article already cited (1987), I discussed the case of the surprisingly radical decentralisation law passed in France in 1982-83. Decentralisation had not come out as an important issue in the 1981 presidential and legislative elections, both won by the left, and it was not clear, when the law was passed, whether it would be an asset for the incumbents at the following election. Thus, I do not deny that the influence of voters was unimportant in the decision to make the law. ${ }^{16}$ In fact, I do not know whether the reform was an asset during the 1986 legislative election, which was dominated by economic and social issues, and which the left in any case lost (see Penniman, 1988). What is clear, however, is that the politicians who were hostile to the law (there were many of them on both sides, but they were the majority on the right) did not raise the issue during that election, nor in the following ones. Presumably, they knew that public opinion had become rapidly attached to the new subcentral institutions and to the new division of powers. Given this support, questioning the reform would have been electorally dangerous. The same kind of stories could be told about the creation of a number of independent authorities, or the granting of more independence to existing ones. Again in France, a case in point is the striking disappearance of opposition to the independence of the central bank granted in the wake of the Maastricht. In earlier work (Salmon, 1995), I have proposed a small model along similar lines to account for the roundabout nature of the transfer of powers to European institutions.

An alternative explanation of many of the phenomena mentioned here could be based on the theoretical framework proposed by Breton in his recent book (1996). Adopting his framework, one should say that what ensures the survival of subcentral governments, supranational institutions or independent authorities is the consent that people give these power centres in exchange for the goods and services that they provide (see especially his chapter 5). Most of the time, I think, the two interpretations come to the same. Not always,

16 Gaston Deferre, at the time simultaneously Minister of the Interior and mayor of Marseilles, was the politician most involved in the design of the law. 
though. In particular, in Breton's account, consent is related to the goods and services that an institution has produced in the past or at the limit is currently producing, whereas I can accept that consent can also be given to institutions that have as yet produced nothing or perhaps do not even exist, except on paper. To account for this possibility, I suggest, one must see voters as being, at least sometime or to some extent, principals within a hierarchical relation rather than buyers on a market. The same need applies, I think, to an issue such as the politicisation of the administration. In France, this issue has several times become a salient one in presidential elections, mostly in the form of a denunciation of, or a warning against, either the 'Etat-RPR' (i.e., 'RPR State') or the 'Etat-PS' (i.e., 'PS State'). ${ }^{17}$ The attention that some voters give to that issue constrains (perhaps increasingly) the proclivity of the party in power to politicise appointments to the top jobs. To generalise, under the perspective that I defend, only voters can be the ultimate guardians of the structural characteristics of the system, including its democratic and competitive characters. ${ }^{18}$

\section{Concluding remarks}

The foregoing discussion has comforted the claim, I hope, that an institution or a set of institutional rules can be entrenched in voters' preferences rather than in a constitution. This is how and why voters have a profound influence on institutional design, as I claimed in the last section. The discussion also suggests that it might be easier to explain why an institution or arrangement endures than to explain how or why it was established or came about in the first place.

\footnotetext{
${ }^{17}$ RPR is for Rassemblement du Peuple Français, the name of the neo-gaullist party; PS is for Parti Socialiste. 18 In the United States, as Robert Inman and Daniel Rubinfeld write (1997, p. 104), "when a political institution did rise to the defense of the federalist constitution - whether it was the executive, the judiciary, or a legislative political party - a single truth prevailed: the vast majority of the citizens in that society believed the federalist constitution to be worth protecting".
} 
To conclude, let me stress an important point. Although I recognised the possibility of constitutional change being initiated from below, all along the paper I rather assumed voters' influence to be typically of a reactive or monitoring kind, the main initiators or producers of change being the politicians. But, for voter's reactions or potential reactions to have an effect, the politicians must take them into account. This means two things. First, the electoral system must favour the influence of voter preferences on politics. In this sense, the electoral system, as noted in Section 2, is a very basic component of the system. If it is of the right, highly competitive type all the rest follows. If not, for instance if it gives too much security to political parties, things become uncertain. Second, the substitution in the literature on elections of probabilistic voting to deterministic voting is a great help toward making the foregoing reasoning plausible. Probabilistic voting means that politicians, insecure about any individual voter's choice, take into account the preferences of all the voters, not only those of the pivotal voter as is the case in non-probabilistic voting. As a consequence, even institutional concerns shared by a minority of voters or, if shared by a majority, considered as secondary by all, are taken into account by politicians or parties submitted to sufficiently tight electoral competition. In other words, institutional or constitutional concerns among voters may be not only negative or latent, as argued earlier, but also relatively weak, and nonetheless constitute an essential underlying cause of the shape taken by institutions.

\section{References}

Ackerman, Bruce (1991). We the People: 1. Foundations. Cambridge, Mass.: The Belknap Press of Harvard University Press.

Ackerman, Bruce (1997). "The Rise of World Constitutionalism". Unpublished paper.

Bernholz, Peter (1997). "Necessary and Sufficient Conditions for a Viable Democracy", in: Albert Breton, Gianluigi Galeotti, Pierre Salmon, and Ronald Wintrobe (eds), Understanding Democracy: Economic and Political Perspectives, Cambridge and New York: Cambridge University Press, pp. 88-103. 
Breton, Albert (1996). Competitive Governments: An Economic Theory of Politics and Public Finance. Cambridge \& New York: Cambridge University Press.

Buchanan, James (1975). The Limits of Liberty. Chicago: Chicago University Press.

Buchanan, James M. (1987). "Constitutional Economics", in: John Eatwell, Murray Milgate and Paul Newman (eds), The New Palgrave: A Dictionary of Economics, London: Macmillan, vol. 1, pp. 585-88.

Buchanan, James M. (1990). "The Domain of Constitutional Economics", Constitutional Political Economy 1, no. 1 (winter), pp. 1-18.

Finn, John E. (1991). Constitutions in Crisis: Political Violence and the Rule of Law. Oxford and New York: Oxford University Press.

Gwartney, James D. and Richard E. Wagner (eds) (1988). Public Choice and Constitutional Economics. Greenwich, Connecticut: JAI Press.

Hardin, Russell (1990). "Contractarianism: Wistful Thinking", Constitutional Political Economy 1, no. 2 (Spring/Summer), pp. 35-52.

Holmström, Bengt and Paul Milgrom (1991). "Multi-Task Principal-Agent Analyses: Incentive Contracts, Asset Ownership, and Job Design". Journal of Law, Economics, and Organization :7, special issue, pp. 24-52.

Inman, Robert P. and Rubinfeld, Daniel L. (1997). "The Political Economy of Federalism", in: Dennis Mueller (ed.), Perspectives on Public Choice: A Handbook, Cambridge and New York: Cambridge University Press, pp. 73-105.

Knott, Jack H. and Gary Miller (1987). Reforming Bureaucracy: The Politics of Institutional Choice. Englewood Cliffs, New Jersey: Prentice-Hall.

Maser, Stephen (1985). "Demographic Factors Affecting Constitutional Decisions: The Case of Municipal Charters". Public Choice 47, pp. 149-62.

McKenzie, Richard B. (ed.) (1984). Constitutional Economics: Constraining the Economic Powers of Government. Lexington, Mass.: D.C. Heath (Lexington Books).

Mueller, Dennis C. (1996). Constitutional Democracy. Oxford and New York: Oxford University Press

Murphy, Walter F. (1993). "Constitutions, Constitutionalism, and Democracy", in: Douglas Greenberg et al. (eds), Constitutionalism and Democracy: Transitions in the Contemporary World, Oxford and New York: Oxford University Press, pp. 3-25.

Niskanen, William A. (1990). "Conditions Affecting the Survival of Constitutional Rules", Constitutional Political Economy 1, no. 2 (Spring-Summer), pp. 53-62. 
Ordeshook, Peter C. (1992). "Constitutional Stability", Constitutional Political Economy 3, no. 2 (Spring-Summer), pp. 136-75.

Penniman, Howard (ed.) (1988). France at the Polls, 1981 and 1986: Three National Elections, Washington, D.C.: American Enterprise Institute (Duke University Press). Salmon, Pierre (1987). "Decentralisation as an Incentive Scheme", Oxford Review of Economic Policy 3, no. 2 (summer), pp. 24-43.

Salmon, Pierre (1991). "Checks and Balances and International Openness", in: Albert Breton, Gianluigi Galeotti, Pierre Salmon, and Ronald Wintrobe (eds), The Competitive State, Dordrecht: Kluwer, pp. 169-84.

Salmon, Pierre (1995). " Nations Conspiring Against Themselves: An Interpretation of European Integration", in: Albert Breton, Gianluigi Galeotti, Pierre Salmon, and Ronald Wintrobe (eds), Nationalism and Rationality, Cambridge and New York: Cambridge University Press, pp. 290-311.

Salmon, Pierre (1997). "Politicians and Bureaucrats: A Relationship Shaped by Voters." Unpublished paper.

Sartori, Giovanni (1994). Comparative Constitutional Engineering: An Inquiry into Structures, Incentives and Outcomes. London: Macmillan.

Tirole, Jean (1994). "The Internal Organization of Government". Oxford Economic Papers 46, no. 1 (January), pp. 1-29.

Vanberg, Viktor (1994). Rules and Choice in Economics. London and New York: Routledge.

Wagner, Richard E. (1987). "Parchments, Guns, and the Maintenance of Constitutional Contract", in: Charles K. Rowley (ed.), Democracy and Public Choice: Essays in Honor of Gordon Tullock, Oxford: Basil Blackwell, pp. 105-121.

Weatherill, Stephen (1995). Law and Integration in the European Union. Oxford and New York: Oxford University Press.

Wittman, Donald A. (1995). The Myth of Democratic Failure: Why Political Institutions are Efficient. Chicago and London: The University of Chicago Press. 
